\title{
31. ORGANIC CARBON, REDUCED SULFUR, AND IRON IN MIOCENE TO HOLOCENE UPWELLING SEDIMENTS FROM THE OMAN AND BENGUELA UPWELLING SYSTEMS ${ }^{1}$
}

\author{
Kay C. Emeis, ${ }^{2}$ John W. Morse, ${ }^{3}$ and Linda L. Mays ${ }^{3}$
}

\begin{abstract}
We examined sediments from Neogene and Quaternary sections of the Benguela and Oman upwelling systems (DSDP Site 532, ODP Sites 723 and 722) to determine environmental and geochemical factors which control and limit pyrite formation in organic-carbon-rich marine sediments.

Those samples from the upwelling sites, which contained low to moderate concentrations of total organic carbon $(0.7 \%-3 \%)$, had C/S ratios typical of normal marine sediments, i.e., around 2.8 . In these sediments, TOC availability probably limited pyrite formation. Results that do not conform with accepted models were found for the sediments high in TOC $(3 \%-12.4 \%)$. The organic matter was of marine origin and contained considerable pyrolytic hydrocarbons, a fact that we take as a sign of low degradation, yet significant concentrations of dissolved sulfate coexisted with it ( $>5$ $\mathrm{mmol} / \mathrm{L}$ in the case of Sites 532 and 723). Detrital iron was probably not limiting in either case, because the degree of pyritization was always less than 0.65 . Therefore, controls on sulfate reduction and pyrite formation in the organic matter-rich sediments do not appear to conform simply to generally accepted diagenetic models. The data from these thermally immature, old, and organic-rich marine sediments imply that (1) the total reduced sulfur content of organic-rich marine upwelling sediments rarely exceeds an approximate boundary of $1.5 \%$ by weight, (2) the C/S ratio of these sediments is not constant and usually much higher than the empirical values proposed for marine sediments. We conclude that sedimentary pyrite formation in upwelling sediments is limited by an as yet unknown factor, and that caution is advised in using $\mathrm{C} / \mathrm{S}$ ratios and $\mathrm{C}$ vs. $\mathrm{S}$ diagrams in paleoenvironmental reconstructions for organic-rich sediments.
\end{abstract}

\section{INTRODUCTION}

Recent investigations of the formation of pyrite have focused on the role of organic matter decomposition via sulfate reduction during shallow burial in marine sediments. Organic matter abundance and composition is perceived as one of three major factors that are generally considered to limit the amount of pyrite formed in sediments. The other two factors are the presence of reactive detrital iron minerals, and availability of dissolved sulfate (e.g., Berner, 1984, 1985). These parameters vary according to the prevailing depositional environment.

Several investigators (e.g., Sweeney, 1972; Goldhaber and Kaplan, 1974; Berner, 1984; Leventhal, 1987) have demonstrated that total organic carbon (TOC) and total reduced sulfur (TRS) correlate positively in sediments, and that the organic carbon to reduced sulfur ratio averages $2.8( \pm 0.8)$ in modern marine sediments deposited beneath oxygenated seawater (e.g., Berner, 1982). Plots of total organic carbon (TOC) vs. total reduced sulfur (TRS) have been used to distinguish different depositional environments, i.e., normal marine (Berner and Raiswell, 1983 1984), euxinic (e.g., Leventhal, 1983), and freshwater (e.g., Davison et al., 1985). In euxinic environments, $\mathrm{H}_{2} \mathrm{~S}$ present in the bottom waters reacts with detrital iron. At low organic matter concentrations this leads to low $\mathrm{C} / \mathrm{S}$ ratios compared with normal marine sediments. In freshwater and brackish environments, where less sulfate is available for reduction, high $\mathrm{C} / \mathrm{S}$ ratios are found (Berner, 1984, 1985; Berner and Raiswell, 1984; Davison et al., 1985). However, C/S ratios are, within a given environment, dependent upon the concentration and quality of TOC and ranges of C/S data are large. This led Raiswell and Berner (1985) to

\footnotetext{
${ }^{1}$ Prell, W. L., Niitsuma, N., et al., 1991. Proc. ODP, Sci. Results, 117: College Station, TX (Ocean Drilling Program).

2 Geologisch-Paläontologisches Institut, Universităt Kiel, 2300 Kiel, Federal Republic of Germany.

3 Department of Oceanography, Texas A\&M University, College Station, Texas 77843, U.S.A.
}

emphasize the utility of $\mathrm{C}$ vs. S plots in interpreting environments.

One goal of this investigation is to examine the concept of determining paleoenvironments based on carbon-sulfur systematics in sediments from marine sections of Neogene to Holocene age. Because the sediments of our sample sets are unweathered and thermally immature, and because their facies are well established from chemical, lithological, and paleontological investigations (e.g., Hay, Sibuet, et al., 1984; Meyers et al., 1984; Prell, Niitsuma, et al., 1989), they constitute ideal targets to test the traditional concepts of pyrite formation. A second objective was to test the method of whole-rock pyrolysis (Rock-Eval) as a means to approximate organic matter character in the context of substrate availability for bacterial fermentation and sulfate reduction. Because of the central importance of organic matter to the process of pyrite formation, we have gone beyond simply determining TOC concentration, and have used Rock-Eval pyrolysis to evaluate the origin of organic matter (Espitalié et al., 1985), and we propose that hydrocarbon yield during pyrolysis may be used to roughly determine its degree of degradation. This concept has been employed previously in order to elucidate the effect of aerobic and anaerobic depositional conditions on organic matter preservation (Pratt et al., 1986; Dean et al., 1986; Davis et al., 1988; Emeis and Morse, 1990; Emeis et al., in press).

\section{STUDY AREAS}

Three sites drilled during Legs 75 and 117 of the Deep Sea Drilling Project and Ocean Drilling Program have been chosen to study the formation of authigenic iron sulfides during diagenesis of sediments in the late Neogene and Quaternary. They are Site 532, situated offshore of southwest Africa in the Benguela upwelling area, and Sites 723 and 722 from the Arabian continental margin underneath the northwest Arabian Sea upwelling area (Fig. 1). The sediments studied range from late Miocene to Pleistocene in age and encompass nearshore and hemipelagic marine deposits, which were deposited under aerobic and dysaerobic to anaerobic conditions in and beneath mid-wa- 
A

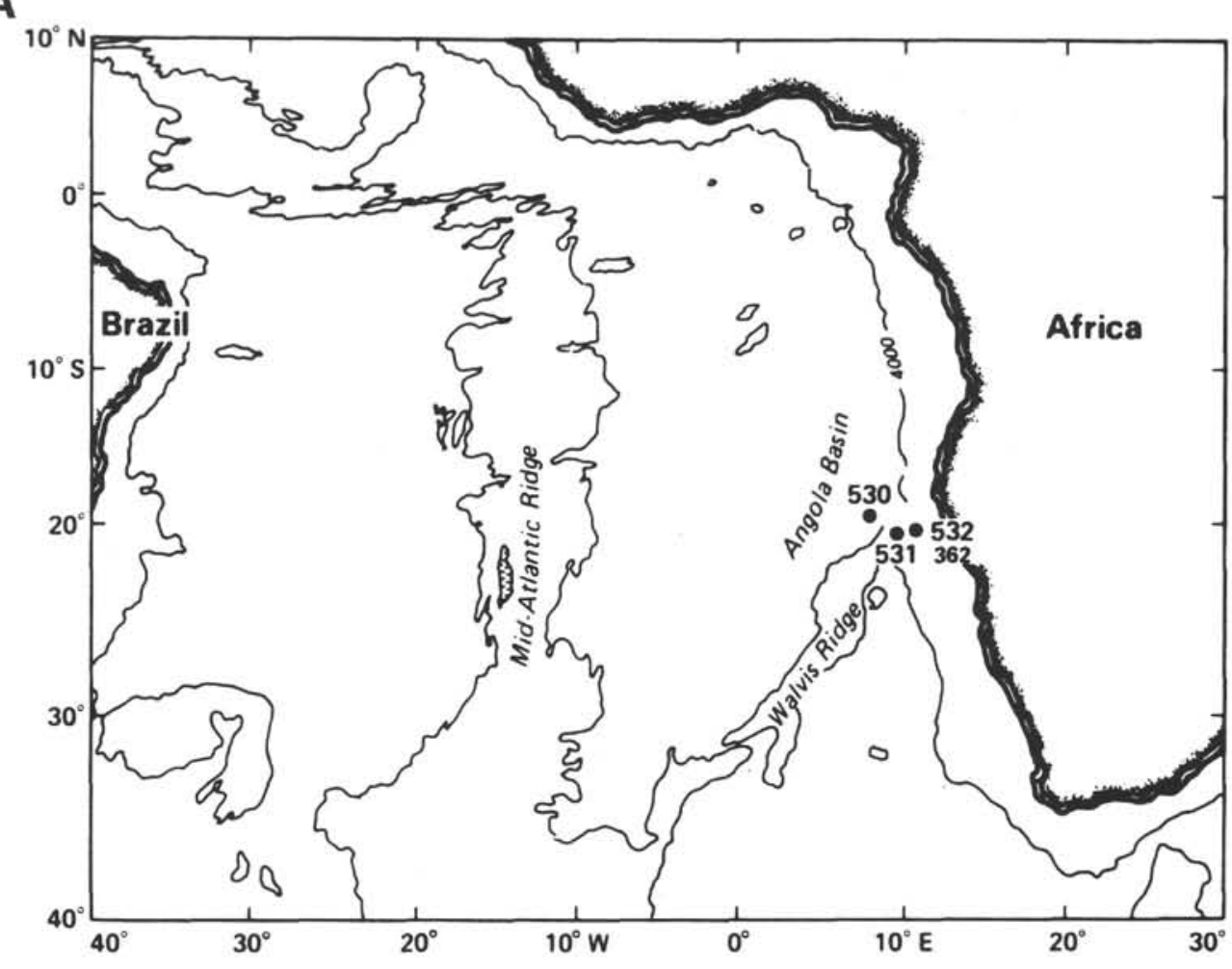

B

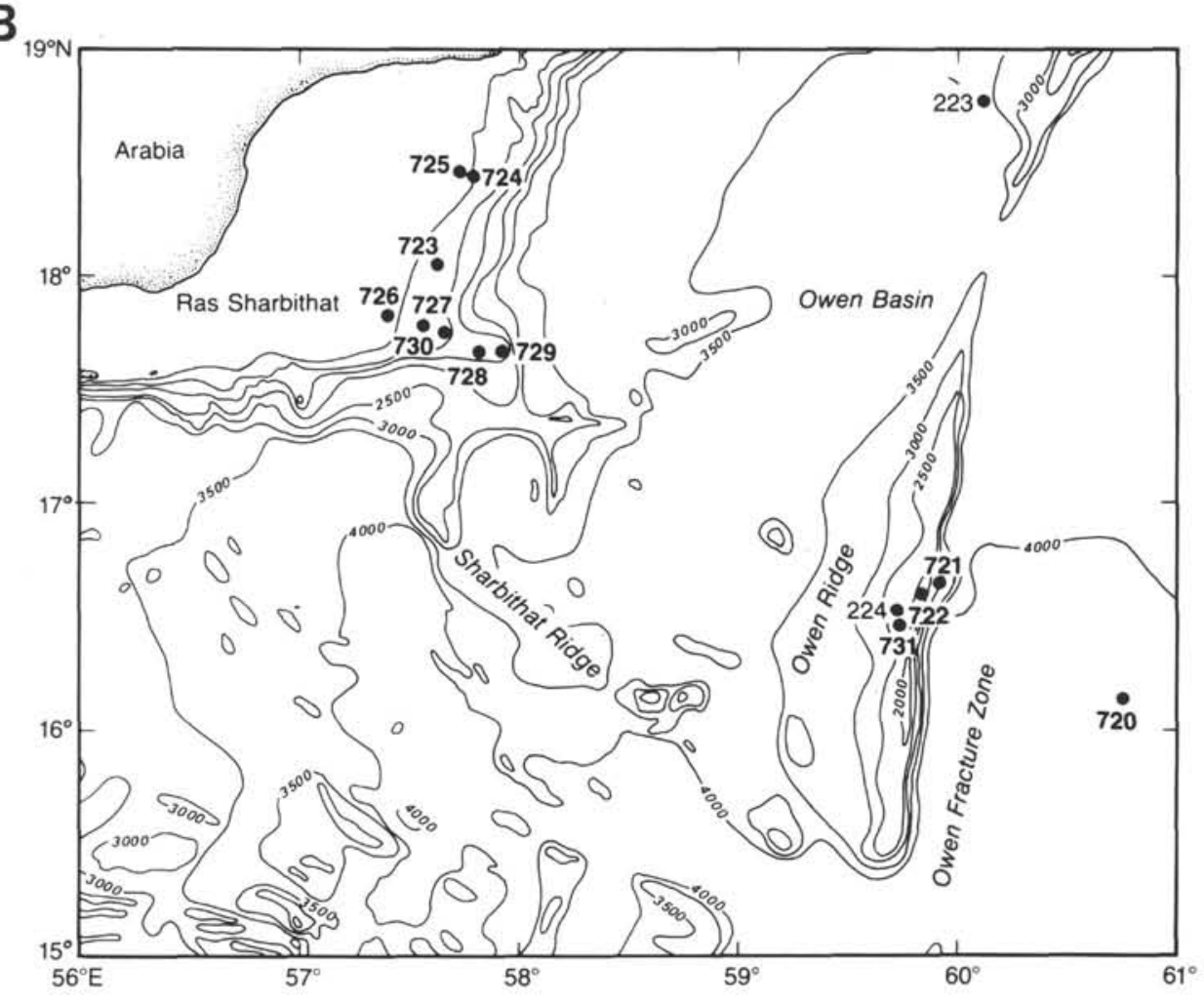

Figure 1. A. Location map of DSDP Site 532 on Walvis Ridge underneath the Benguela upwelling area. B. Location of Sites 722 and 723 drilled during Leg 117 . 
ter oxygen-minimum zones (Hay, Sibuet, et al., 1984; Prell, Niitsuma, et al., 1989). Similarity in facies and dominant input by calcareous nannofossils distinguishes these sites from those studied by Emeis and Morse (1990) on the Peru margin, where primary production is dominated by diatoms.

Site 532, DSDP Leg 75, is located on the eastern part of the Walvis Ridge on the Southwest African continental margin. The dominant lithology is hemipelagic calcareous and siliceous biogenic ooze that accumulated at rates between 25 and $50 \mathrm{~m} / \mathrm{m}$.y. and that shows pronounced dark-light cyclicity on a scale of meters. From smear slide analyses, Hay, Sibuet, et al. (1984) estimate that individual biogenic components range from $80 \%$ to $90 \%$ in Pleistocene and Pliocene sediments. Clay-sized clastic material accounts for $10 \%-20 \%$ in the Pleistocene section, and increases downhole to $50 \%$ in the late Miocene. In the biogenic fraction, nannofossils range from $20 \%$ to $50 \%$ and diatoms are present in quantities of $10 \%-40 \%$ in late Pliocene strata. The opal-rich late Pliocene sediment is also characterized by a peak in TOC concentrations of up to $8.65 \%$. The increase in diatoms and TOC in the late Pliocene reflects an increase in primary productivity and a strengthening of the Benguela upwelling system (Meyers et al., 1983, 1984).

Site $723\left(18^{\circ} 03.079^{\prime} \mathrm{N}\right.$ and $\left.57^{\circ} 36.561^{\prime} \mathrm{E}\right)$ was drilled in water $808 \mathrm{~m}$ deep and recovered uppermost Pliocene to Holocene(?) foraminifer-bearing nannofossil oozes to calcareous clayey silts (Fig. 2). The sedimentation rate is high throughout the section (approximately $200 \mathrm{~m} / \mathrm{m} . y$.) and records variability in eolian and biogenic input during the depositional period in great detail (Prell, Niitsuma, et al., 1989). Abundance of TOC and the occurrence of laminations in intervals of latest Pliocene to early Pleistocene suggest that bottom-water oxygen contents were lower and precluded bioturbation; the resulting laminated sequences coincide with strata that were cemented by dolomite during diagenesis, and in which biogenic silica was preserved.

Site 722 is located on Owen Ridge $\left(16^{\circ} 37.312^{\prime} \mathrm{N}\right.$ and $59^{\circ} 47.755^{\prime} \mathrm{E}$ ) in water $2030 \mathrm{~m}$ deep. The oldest sediments here are early Miocene silty claystones, but the dominant lithology is nannofossil ooze to diatomaceous nannofossil ooze with lighter and darker colored alternations on a scale of meters. Coincident with dark colors are TOC concentrations $>2 \%$ by weight, and a decrease in $\mathrm{CaCO}_{3}$. We studied organic matter character and sulfide content across one of the cyclic light-dark intervals in Core 722A-16X (146-147 mbsf) and in a few sediments from other depths, hoping to find a clue to the depositional conditions leading to the light-dark cyclicity and their chemical fingerprint.

\section{EXPERIMENTAL METHODS}

Samples of Holes 723A and 722A were freeze dried and ground immediately after core splitting on board ship; those of Hole 532B were immediately frozen upon core retrieval, and freeze dried after shipment. The nature of the organic matter and organic carbon concentration was measured by Rock-Eval pyrolysis (Espitalié et al., 1985). The parameters determined by Rock-Eval pyrolysis that are used here are TOC, the hydrogen index (HI, in mg hydrocarbons/g TOC), and the oxygen index (OI, in $\mathrm{mg} \mathrm{CO} / \mathrm{g}$ TOC) as determined after standardization with an appropriate standard (IFP 55000).

By using Rock-Eval pyrolysis results of immature marine sediments, we attempt to address the question of organic matter composition, i.e., its degree of refraction and its origin, which are crucial parameters that exert control on the extent of microbial sulfate reduction of sedimentary organic matter. Wholerock pyrolysis is a standard tool of hydrocarbon exploration to determine the origin and thermal maturity of insoluble organic matter (kerogen) in hydrocarbon source rocks. The method is based on the assumption that organic matter of aquatic sources

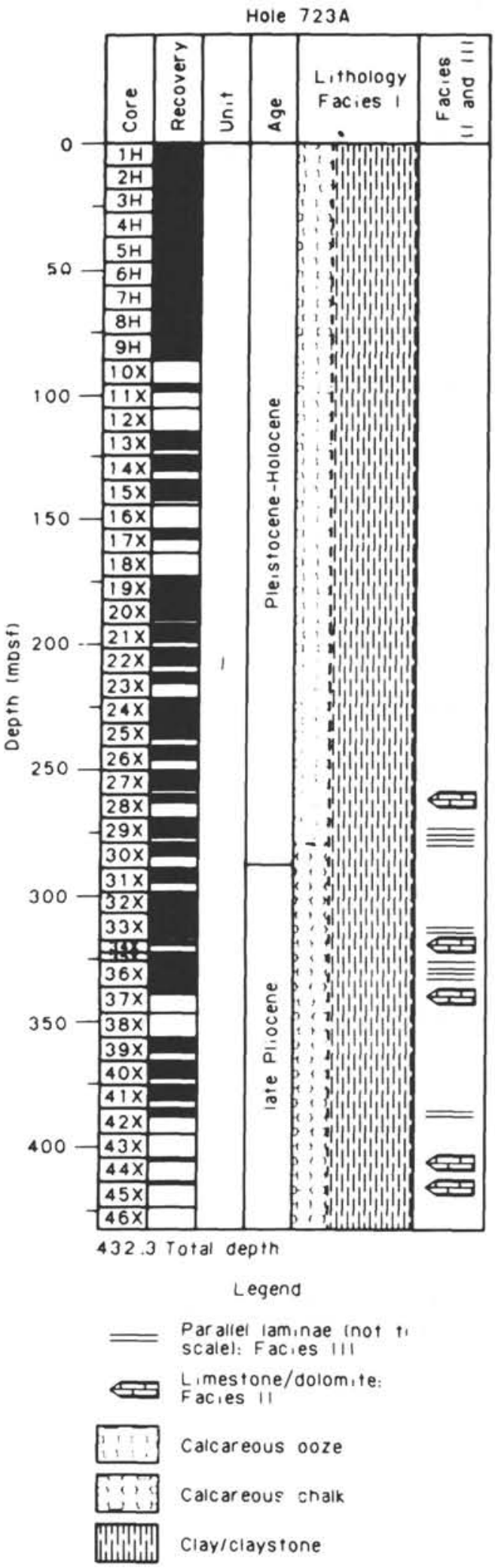

Figure 2. Lithologic summary and stratigraphy of Site 723. 
is richer in hydrogen (i.e., in lipids) than terrestrial organic matter, which contains relatively more oxygen (i.e., in carbohydrates and lignin).

Most immature sediments of marine origin contain organic matter in the range of $0.2 \%$ to $0.5 \%$ (Hunt, 1972) that has undergone severe microbial degradation. As a consequence, the humic substance of marine sediments is a highly condensed polymer of complex structure. The condensation to macromolecular compounds severely hampers complete characterization of the proto-kerogen, and commonly monitored labile compounds of TOC (e.g., amino compounds, carbohydrates, hydrocarbons, chlorins) rarely contribute more than $10 \%$ of the entire TOC. This proto-kerogen, however, still contains more hydrogen-bearing and heterocompounds (N,S,O-bearing molecules) when compared to thermally mature kerogen and terrestrial organic matter, and the abundance of pyrolyzable compounds (of which hydrocarbons are a sizable portion; Emeis et al., in press) may be a good, if crude, approximation of the substrate quality for bacterial fermentation and sulfate reduction. The abundance of pyrolytic hydrocarbons normalized to TOC, i.e., the hydrogen index, may thus be useful to distinguish high degrees of biodegradation from moderate to low degradation (based on the ratio of $\mathrm{HI}$ to organic carbon, i.e., the ratio of labile lipid-rich material to TOC). We are aware that a stringent and traditional use of pyrolysis parameters is problematic in the context of most immature sediments, because errors at low organic matter concentrations lead to erratic and exaggerated numbers, and the general perception is that $\mathrm{HI}$ and $\mathrm{OI}$ are only meaningful at TOC $>1 \%$. Such low values are scarce in case of the upwelling sediments studied here, and rarely do the TOC values drop below a threshold of $1 \%$ TOC, below which mineral matrix effects may interfere with the hydrocarbon yield during pyrolysis (Katz, 1983). The upwelling sediments are therefore uniquely suited for our purpose.

To verify TOC measurements with the Rock-Eval instrument, TOC in samples from all sites was determined by subtracting carbonate- $\mathrm{C}$ from total-C obtained from combustion in a $\mathrm{CHN}$ Elemental Analyzer (Perkin Elmer Model 240). The method used on samples from Site 532 also yields the concentration of total nitrogen in the sample. We found that the TOC determinations with both instruments agree well in the case of the sample sets studied here. All TOC concentrations given in the tables are those derived by the difference method. Carbonate determinations were performed on a Coulometrics $\mathrm{CO}_{2}$ Analyzer after acidification with $2 \mathrm{~N} \mathrm{Hcl}$.

Total inorganic reduced sulfur (TRS) was measured on all samples and determined by the Cr(II) reduction technique of Zhabina and Volkov (1978), as modified by Canfield et al. (1986). The method to measure acid-volatile sulfides (AVS; Westrich, 1983) uses cold $6 \mathrm{~N} \mathrm{HCl}$ and stannous chloride. Extracted sulfide concentrations were determined by titration with $\mathrm{Pb}$ $\mathrm{ClO}_{4}$, using a silver-sulfide reference electrode. All AVS concentrations were below our detection limit of $4 \mathrm{mmol} / \mathrm{g}$, and we have taken the total inorganic reduced sulfur fraction to be representative of TRS. Iron was measured after extraction with cold $1 \mathrm{~N} \mathrm{HCl}$ for $12 \mathrm{hr}$ and analyzed by flame atomic absorption spectrometry to give a measure of reactive iron abundances and to calculate the degree of pyritization (Berner, 1970). The degree of pyritization (DOP) is given as

$$
\text { DOP }(\text { molar ratio })=\text { Pyrite }_{\mathrm{Fe}} /\left(\text { Pyrite }_{\mathrm{Fe}}+\text { Reactive }_{\mathrm{Fe}}\right) \text {, }
$$

where Pyrite Fe $_{\mathrm{Fe}}$ is well approximated as 0.5 TRS, based on the molar ratio of iron and sulfur in pyrite. In the past various acid concentrations have been used to extract reactive iron (e.g., Berner, 1970, used hot $12 \mathrm{~N} \mathrm{HCl}$, while Canfield, 1989, used a sequential extraction that ended with a sodium dithionite solu- tion of $\mathrm{pH}=4.8$ ). Consequently, our calculated degrees of pyritization may be different from those derived from other iron extraction techniques; it was pointed out that our "reactive" iron may actually include iron from iron-bearing silicates.

Average $\mathrm{C} / \mathrm{S}$ ratios were calculated from the ratio of average TOC and average TRS values. Other uncertainties are reported as standard deviations.

\section{RESULTS}

\section{Site $\mathbf{5 3 2}$}

The highly productive Benguela upwelling system, where sedimentation rates range from 25 to $62 \mathrm{~m} / \mathrm{m}$.y., resulted in considerable burial of TOC at Site 532 beneath oxygenated bottom waters since the Miocene (Hay, Sibuet, et al., 1984). Data from this site are presented in Table 1. Organic carbon concentrations are highly variable in interlayered light/dark hemipelagic oozes and range from $0.70 \%$ to $8.65 \%$, with an average of $3.97 \%$. Maximum TOC values occur in the late Pliocene at about 100 mbsf, an increase that is accompanied by an increase in biogenic silica and has been attributed to an increase in primary productivity and a higher degree of preservation. Below this peak, TOC concentrations are considerably lower.

Fairly uniform organic $\mathrm{C} / \mathrm{N}$ ratios at Site 532 average 12.9 and range from 8.6 to 15.9 (see also Hay, Sibuet, et al., 1984). Analysis of macerals and lipids (Rullkötter et al., 1984; Meyers and Dunham, 1984) corroborate the finding of pyrolysis that the bulk of the organic matter in the sediments recovered at Site 532 is of marine origin, even though contributions from terrestrial sources were apparent in all methods. Concentrations of TRS range from 0.24 to $1.44 \mathrm{wt} \%$. The relation between TOC and TRS is illustrated in Figure 3. The upper $100 \mathrm{~m}$ of the section has an average $\mathrm{C} / \mathrm{S}$ value of $5.83( \pm 2.18, \mathrm{n}=15)$, which decreases to $3.33( \pm 1.08, \mathrm{n}=17)$ below $125 \mathrm{~m}$. These ratios are at the high end of values for normal marine environments.

Acid-soluble $\mathrm{Fe}$ concentrations range from 0.38 to $0.92 \mathrm{wt} \%$. The DOP exhibits a rather narrow range of 0.45 to 0.63 . These intermediate DOP values indicate that $\mathrm{Fe}$ was probably not limiting for pyrite formation in these sediments. Also, the sulfate concentrations are high enough $(4.9-31 \mathrm{mmol} / \mathrm{L})$ to indicate that it was not a limiting factor for pyrite formation (Gieskes et al., 1984; Berner, 1985). Organic matter character from pyrolysis in Hole 532B clusters in an area that is characteristic of immature marine organic matter in a plot of the HI vs. OI (Fig. 4). As can be seen in Figure 5, a loose correlation exists between the two parameters HI and TOC for samples from Hole 532B. This positive correlation implies that the labile, hydrogen-rich components are more abundant at high TOC preservation. Because the relationship should be constant at uniform composition of the organic matter (the $\mathrm{HI}$ is normalized to organic carbon abundance), we interpret this correlation as an indication of preferential preservation of hydrogen-bearing organic material at high TOC burial (Pratt et al., 1986).

\section{Sites 723 and 722}

TOC concentrations in sediments from Site 723 average 3.17 wt $\%$, and show a peak in upper Pliocene to lower Pleistocene laminated and biosiliceous oozes (Prell, Niitsuma, et al., 1989; see Table 2). In contrast to samples from Site 532, no correlation is apparent in a plot of TOC vs. HI. The average HI is 351 in the sample set from Site 723 (Fig. 5). TRS concentrations exhibit a wide scatter relative to TOC (Fig. 3). The average TRS concentration in sediments from Site 723 is $0.47 \mathrm{wt} \%$. This value is about half that observed for sediments from Site 532 .

A possible explanation for the lower TRS values at Site 723 is that they may arise from higher calcium carbonate content of the sediments. Although the TOC content of the sediments does 
Table 1. Results of analyses for Site 532. n.d. = not determined.

\begin{tabular}{|c|c|c|c|c|c|c|c|c|c|c|}
\hline $\begin{array}{l}\text { Core, section, } \\
\text { interval }(\mathrm{cm})\end{array}$ & $\begin{array}{l}\text { Depth } \\
\text { (mbsf) }\end{array}$ & $\begin{array}{l}\mathrm{CaCO}_{3} \\
\text { (wt } \% \text { ) }\end{array}$ & $\begin{array}{l}\text { TOC } \\
(w t \%)\end{array}$ & $\mathrm{C} / \mathrm{N}$ & $\begin{array}{l}\text { TRS } \\
\text { (wt \%) }\end{array}$ & $\mathrm{C} / \mathrm{S}$ & $\begin{array}{l}\mathrm{Fe}(\mathrm{sol}) \\
\text { (wt \%) }\end{array}$ & $\begin{array}{c}\text { DOP } \\
\text { (molar) }\end{array}$ & HI & OI \\
\hline $2 \mathrm{H}-2,75-82$ & 5.7 & 28.50 & 2.11 & 10.6 & 0.42 & 5.0 & 0.45 & 0.45 & 338 & 231 \\
\hline $4 \mathrm{H}-2,29-39$ & 14.0 & 14.00 & 5.09 & 12.7 & 0.76 & 6.7 & n.d. & n.d. & 411 & 147 \\
\hline $5 \mathrm{H}-3,12-22$ & 19.7 & 33.10 & 1.67 & 12.9 & 0.29 & 5.8 & n.d. & n.d. & 375 & 244 \\
\hline $13 \mathrm{H}-1,28-41$ & 52.1 & 18.70 & 5.62 & 11.7 & 0.94 & 6.0 & n.d. & n.d. & 264 & 89 \\
\hline $13 \mathrm{H}-2,56-65$ & 53.9 & 12.70 & 4.46 & 13.5 & 0.85 & 5.2 & n.d. & n.d. & n.d. & n.d. \\
\hline $17 \mathrm{H}-2,10-16$ & 71.0 & 5.70 & 5.12 & 13.1 & 1.44 & 3.6 & 0.92 & 0.58 & 501 & 145 \\
\hline $17 \mathrm{H}-2,54-68$ & 71.4 & 16.00 & 2.93 & 12.3 & 0.78 & 3.8 & n.d. & n.d. & 316 & 164 \\
\hline $22 \mathrm{H}-1,30-40$ & 91.7 & 10.30 & 5.52 & 15.9 & 0.94 & 5.9 & n.d. & n.d. & 300 & 81 \\
\hline $22 \mathrm{H}-2,24-38$ & 93.1 & 17.30 & 3.90 & 10.8 & 0.63 & 6.2 & n.d. & n.d. & 258 & 96 \\
\hline $22 \mathrm{H}-2,52-56$ & 93.4 & 12.10 & 7.43 & 14.1 & 1.20 & 6.2 & n.d. & n.d. & 314 & 88 \\
\hline $22 \mathrm{H}-2,56-60$ & 93.5 & 12.60 & 7.84 & 14.2 & 1.14 & 6.9 & n.d. & n.d. & 340 & 85 \\
\hline $22 \mathrm{H}-2,72-76$ & 93.6 & 7.20 & 8.65 & 15.2 & 1.26 & 6.9 & n.d. & n.d. & 344 & 88 \\
\hline $22 \mathrm{H}-2,80-84$ & 93.7 & n.d. & 6.43 & 14.7 & 1.20 & 5.4 & n.d. & n.d. & 423 & 92 \\
\hline $22 \mathrm{H}-2,84-88$ & 93.7 & 12.90 & 6.01 & 14.6 & 1.02 & 5.9 & n.d. & n.d. & 371 & 88 \\
\hline $22 \mathrm{H}-2,88-92$ & 93.8 & 11.50 & 8.45 & 14.0 & 1.13 & 7.5 & n.d. & n.d. & 347 & 70 \\
\hline $27 \mathrm{H}-3,70-83$ & 116.7 & 16.30 & 1.94 & 13.5 & 0.75 & 2.6 & 0.38 & 0.63 & 278 & 149 \\
\hline $34 \mathrm{H}-2,25-30$ & 143.6 & 17.30 & 2.59 & 13.3 & 0.56 & 4.6 & n.d. & n.d. & 283 & 147 \\
\hline $34 \mathrm{H}-2,34-41$ & 143.7 & 18.90 & 3.96 & 13.2 & 0.97 & 4.1 & n.d. & n.d. & 182 & 88 \\
\hline $34 \mathrm{H}-2,48-54$ & 143.8 & 16.40 & 3.16 & 12.1 & 0.90 & 3.5 & n.d. & n.d. & 169 & 124 \\
\hline $34 \mathrm{H}-2,18-126$ & 144.5 & 24.60 & 3.11 & 13.2 & 0.74 & 4.2 & n.d. & n.d. & 172 & 128 \\
\hline $43 \mathrm{H}-2,00-108$ & 179.7 & 16.90 & 1.99 & 13.1 & 0.76 & 2.6 & n.d. & n.d. & 229 & 157 \\
\hline $43 \mathrm{H}-3,06-12$ & 180.3 & 14.00 & 4.34 & 14.6 & 1.12 & 3.9 & 0.63 & 0.61 & 340 & 110 \\
\hline $43 \mathrm{H}-3,19-26$ & 180.4 & 20.70 & 3.99 & 13.2 & 1.07 & 3.7 & n.d. & n.d. & 274 & 106 \\
\hline $43 \mathrm{H}-3,26-32$ & 180.5 & 15.90 & 3.60 & 14.2 & 0.94 & 3.8 & 0.76 & 0.52 & 294 & 114 \\
\hline $47 \mathrm{H}-2,43-55$ & 194.0 & 26.80 & 1.61 & 11.3 & 0.72 & 2.2 & 0.47 & 0.47 & 242 & 186 \\
\hline $47 \mathrm{H}-2,55-67$ & 194.2 & 24.50 & 2.19 & 12.7 & 0.85 & 2.6 & n.d. & n.d. & 240 & 144 \\
\hline $47 \mathrm{H}-2,16-130$ & 194.8 & 41.60 & 3.85 & 11.8 & 1.02 & 3.8 & n.d. & n.d. & 194 & 102 \\
\hline $56 \mathrm{H}-1,64-70$ & 229.0 & 22.50 & 1.62 & 11.4 & 0.84 & 1.9 & 0.47 & 0.61 & 199 & 166 \\
\hline $56 \mathrm{H}-1,85-91$ & 229.3 & 20.10 & 3.07 & 12.1 & 1.02 & 3.0 & n.d. & n.d. & 256 & 131 \\
\hline $56 \mathrm{H}-1,97-105$ & 229.4 & 22.60 & 2.68 & 11.9 & 0.79 & 3.4 & 0.50 & 0.58 & 210 & 127 \\
\hline $56 \mathrm{H}-1,19-126$ & 229.6 & 28.40 & 0.70 & 8.6 & 0.24 & 2.9 & n.d. & n.d. & 161 & 288 \\
\hline $66 \mathrm{H}-3,44-49$ & 267.1 & 24.80 & 1.43 & 11.5 & 0.50 & 2.9 & 0.50 & 0.47 & 258 & 191 \\
\hline Mean & & 18.87 & 3.97 & n.d. & 0.87 & 4.6 & 0.56 & 0.55 & 287 & 134 \\
\hline Standard deviation & & 7.70 & 2.14 & n.d. & 0.28 & n.d. & 0.17 & 0.07 & 81 & 52 \\
\hline Minimum & & 5.70 & 0.70 & 8.6 & 0.24 & 1.9 & 0.38 & 0.45 & 161 & 70 \\
\hline Maximum & & 41.60 & 8.65 & 15.9 & 1.44 & 7.5 & 0.92 & 0.63 & 501 & 288 \\
\hline
\end{tabular}

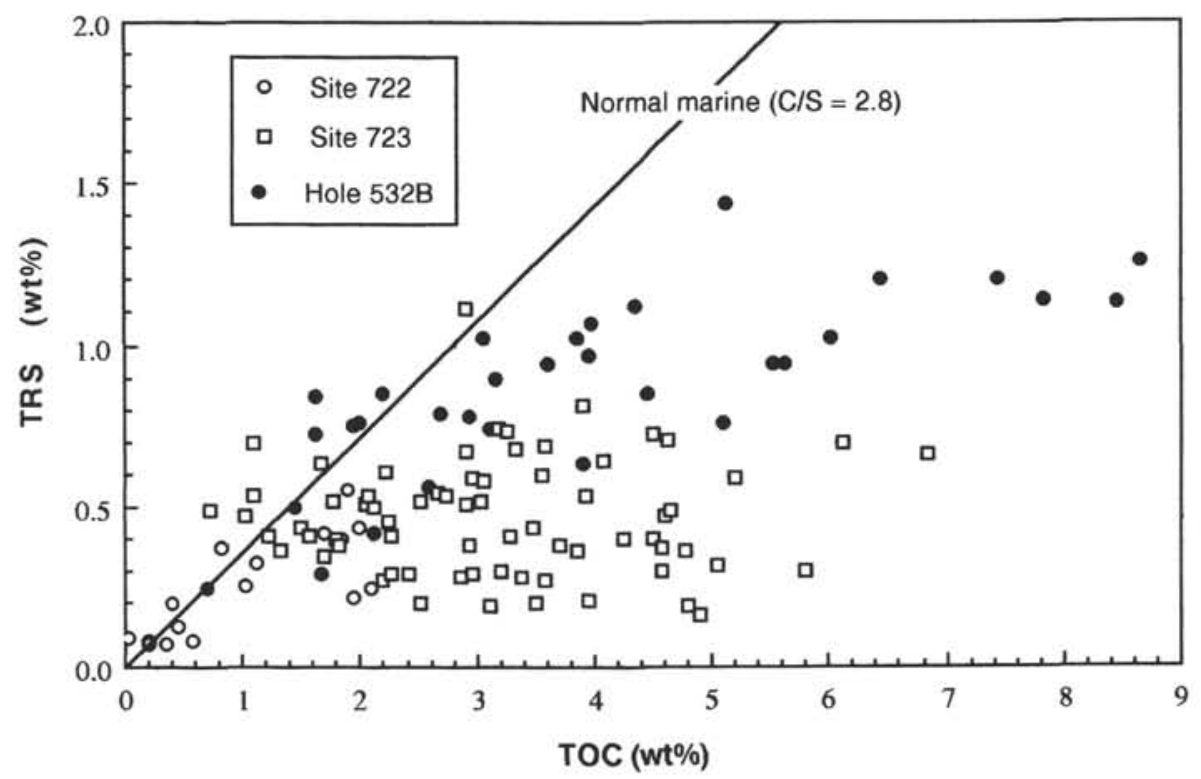

Figure 3. Organic carbon to reduced sulfur weight ratios in samples from the Oman margin and Benguela upwelling. Note the lack of correlation for samples from Site 723. 


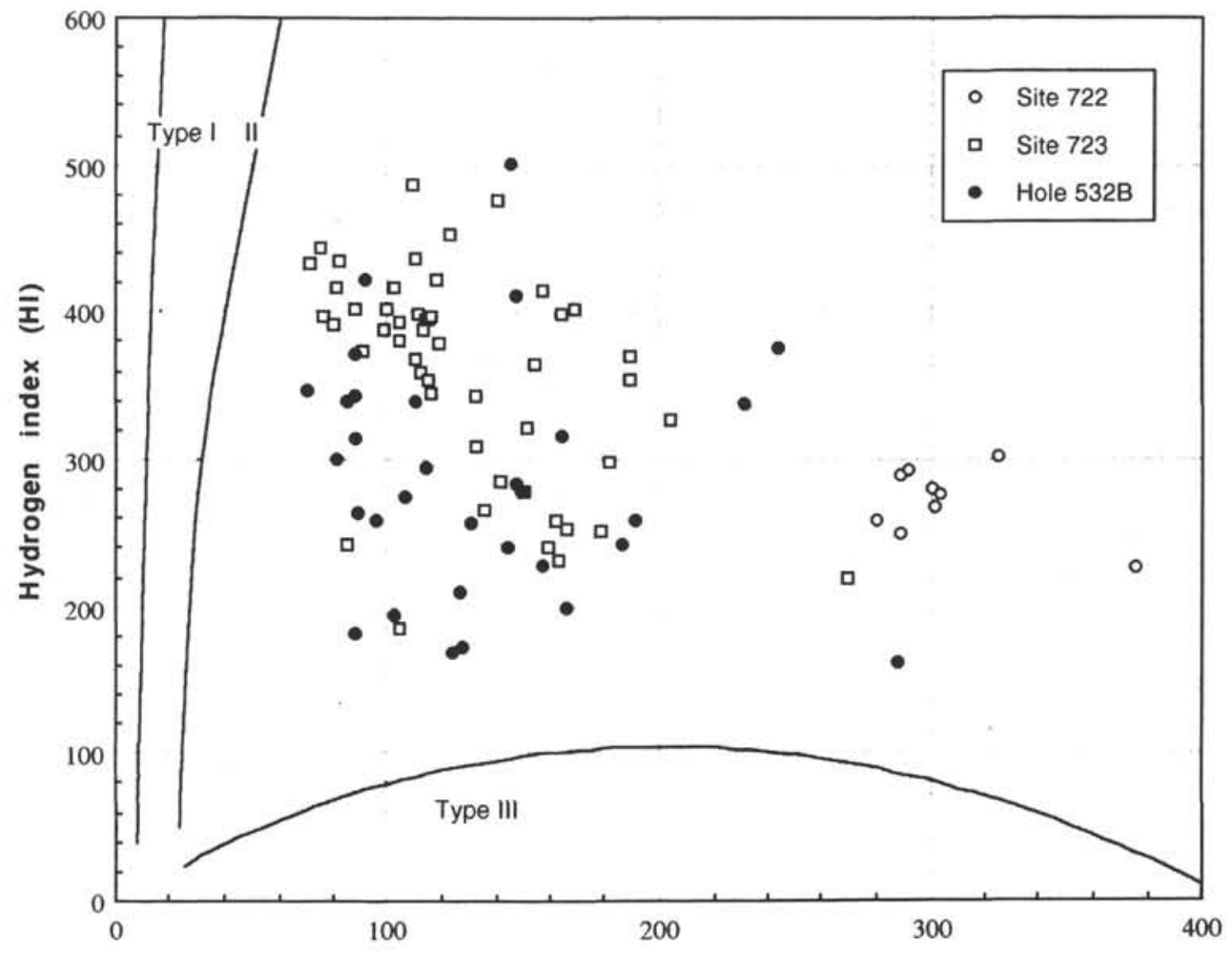

Oxygen index (OI)

Figure 4. Plot of HI vs. OI for samples studied here. All samples can be considered to contain predominantly marine organic matter rich in hydrogen-bearing molecules. A shift to lower HI and higher OI, i.e., to the evolution path of kerogen type III (terrestrial material), may be effected by advanced bacterial degradation of kerogen and proto-kerogen due to recycling and reworking of sediment and organic matter.

not correlate with $\mathrm{CaCO}_{3}$ (Fig. 6A), TRS exhibits a significant negative correlation with $\mathrm{CaCO}_{3}$. When TRS and TOC are calculated on a $\mathrm{CaCO}_{3}$-free basis, we recognize a considerable overlap between values from Sites 532 and 723 (Fig. 6B), and the mean TRS concentrations, calculated on a $\mathrm{CaCO}_{3}$-free basis, is almost identical (Site $532=1.07 \mathrm{wt} \%$, Site $723=1.04$ wt \%). This is an interesting similarity, because it is the same value as is found in sediments from the upwelling system offshore Peru (Emeis and Morse, 1990). At present, we are uncertain whether the similarities are coincidental, or whether they are expressions of more fundamental and as yet unrecognized processes controlling TRS formation in organic-rich marine sediments.

While the mean TRS concentrations, calculated on a $\mathrm{CaCO}_{3}$ free basis, are almost identical at these sites, mean corrected TOC concentrations are considerably different $(4.9 \mathrm{wt} \%$ at Site $532,7.0 \mathrm{wt} \%$ at Site 723$)$, as are mean DOP values $(0.55$ at Site $532,0.42$ at Site 723 ). The differences in mean TOC concentrations are reflected in the differences in mean C/S ratios of 4.6 at Site 532 and 6.8 at Site 723 . Both values are considerably higher than the typical value of 2.8 for "normal marine" sediments.

A limited number of samples measured from Site 722 make interpretations of results for ridge sediments more tenuous. Average TOC concentrations in the hemipelagic sediments from Site 722 are $1.2 \mathrm{wt} \%$, and a mean of $0.29 \mathrm{wt} \%$ TRS results in an average $\mathrm{C} / \mathrm{S}$ wt ratio of 4.1 (Table 3 ). The samples studied from this site are low in TOC, and their hydrogen and oxygen indices show that organic matter is in part degraded and oxidized marine material with a considerable proportion of terrestrial organic matter. The small number of samples and the lack of iron data for this site make it difficult to judge the effects of increased organic-matter burial in dark members of the light/ dark cyclicity on reduced sulfur concentrations. TRS and TOC appear to be correlated positively, but values never exceed 0.5 wt $\%$ TRS in the organic-matter-rich dark intervals that have the highest hydrogen indexes.

\section{DISCUSSION}

This study was undertaken to investigate the organic carbonauthigenic sulfide system in Neogene and Quaternary sediments which have not been exposed to major secondary processes, such as exposure to weathering or meteoric ground waters. The Benguela and Oman margin upwelling sites were chosen because the environment was marine, with sediments which have major variations in TOC content primarily associated with the intensity of upwelling. It was consequently possible to investigate the influence of TOC concentration on the sedimentary sulfide system under relatively constant environmental conditions. Our investigation differs from previous work in that it attempts to address the problem of pyrite formation in sedimentary environments, where the diagenetic zone of sulfate reduction is vastly expanded as compared to more frequently investigated nearshore sediments. Even though the amount of sulfate reduced and sulfide formed in the sediment below the immedi- 


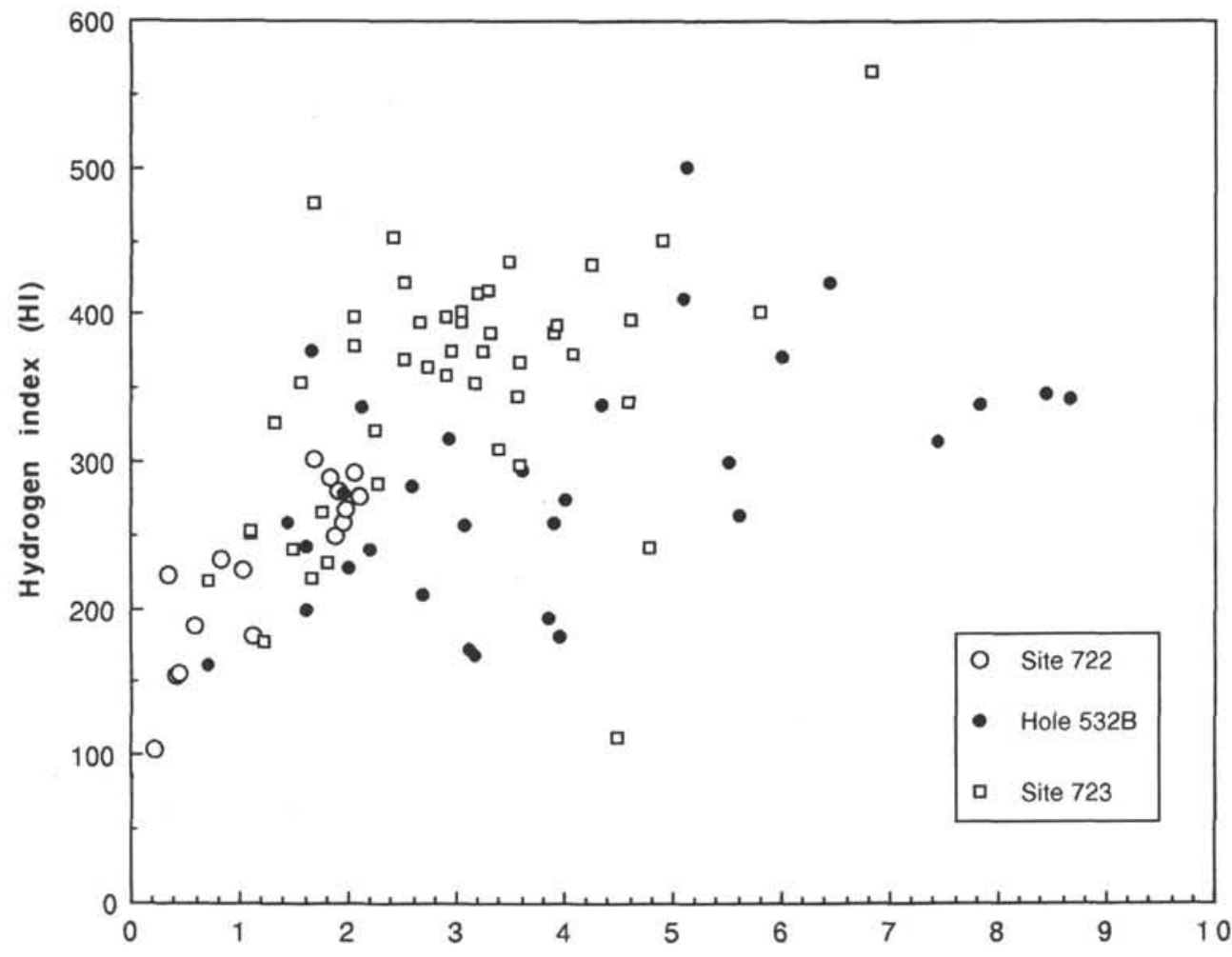

TOC (wt\%)

Figure 5. Diagram of TOC vs. HI for samples studied here. Note the lack of correlation for Site 723.

ate sediment/water interface decreases exponentially with depth, and much of the sulfide thus formed may be reoxidized in microbially mediated reactions, we can test the generally accepted model for pyrite formation in an environment of slow turnover rates.

The three primary factors which are generally considered to limit formation of sulfides in sediments are dissolved sulfate, reactive iron minerals, and metabolizable organic matter (e.g., Berner, 1970). In samples from both Sites 532 and 723 sulfate concentrations in pore waters are not depleted to the point where sulfate was limiting, and the moderate DOP $(<0.65)$ of iron implies that reactive iron may not be limiting either. (It should be noted that we used a less harsh method for determining the DOP than has traditionally been used. The harsher methods would probably have given even lower DOP values.) Consequently, it would be reasonable to expect that metabolizable organic matter was the limiting component for sulfide mineral formation in these sediments, as it is in many normal marine sediments (Berner, 1984).

However, there are generally high concentrations of organic matter present in all samples of the unconsolidated and thermally immature sedimentary section from both Sites 532 and 723. Pyrolysis results of Site 723 suggest that the organic matter is not degraded to the point that it could limit sulfate reduction (Emeis et al., this volume). Westrich and Berner (1984) have demonstrated that it is not simply the quantity, but also the quality of organic matter which determines the pool of metabolizable TOC in sediments. In most samples from Sites 532 and 723 , the hydrogen-rich labile constituents were abundant; Davis et al. (1988) found that an $\mathrm{HI}$ of 150 limited sulfate reduction in black shales of Cretaceous age. It appears that a sufficient pool of metabolizable organic matter is present in our set of samples for sulfate reduction to proceed.

These results present a dilemma for understanding what controls sedimentary sulfide production in these TOC rich marine sediments, because none of the factors traditionally considered limiting, e.g., labile organic matter, sulfate, and iron, are at low enough concentrations to limit pyrite formation. Sulfate is unambiguously not limiting. The fact that we often observe much higher $(>0.8)$ DOP values in other sediments is suggestive that the low DOP's observed here are not grossly misleading in indicating that reactive $\mathrm{Fe}$ is probably not limiting.

Even if reactive $\mathrm{Fe}$ does limit pyrite production, the coexistence of the sulfate with high concentrations of only moderately degraded organic matter for millions of years remains unexplained. Work performed in our laboratory on ODP sediments from beneath the Peru upwelling systems is yielding similar results (Emeis and Morse, 1990). For some reason bacterial sulfate reduction fails to proceed as far as would be expected in organic-rich, hemipelagic marine sediments from beneath highly productive upwelling systems. This may be caused by some not yet understood aspect of bacterial ecology, and is certainly worthy of further investigation.

Raiswell and Berner (1987) have recently examined many of the factors which influence $\mathrm{C} / \mathrm{S}$ ratios in the post-depositional environments encountered in ancient sediments. They emphasized the need to use a large number of samples in drawing conclusions about depositional environments. It was also pointed out that the influences of many of the factors encountered in this study, such as subsurface supply of sulfate from evaporitic 
Table 2. Results of analyses for Site $\mathbf{7 2 3}$.

\begin{tabular}{|c|c|c|c|c|c|c|c|c|c|}
\hline $\begin{array}{l}\text { Core, section, } \\
\text { interval }(\mathrm{cm})\end{array}$ & $\begin{array}{l}\text { Depth } \\
\text { (mbsf) }\end{array}$ & $\begin{array}{l}\mathrm{CaCO}_{3} \\
(\mathrm{wt} \%)\end{array}$ & $\begin{array}{c}\text { TOC } \\
(w t \%)\end{array}$ & $\begin{array}{l}\text { TRS } \\
(w t \%)\end{array}$ & $\mathrm{C} / \mathrm{S}$ & $\begin{array}{l}\mathrm{Fe}(\mathrm{sol}) \\
(\mathrm{wt} \%)\end{array}$ & $\begin{array}{l}\text { DOP } \\
\text { molar }\end{array}$ & HI & OI \\
\hline $1-1,43-44$ & 0.4 & 53.7 & 5.80 & 0.30 & 19.1 & n.d. & n.d. & 402 & 169 \\
\hline $1-1,113-114$ & 1.1 & 60.1 & 4.80 & 0.19 & 25.7 & 0.27 & 0.37 & n.d. & n.d. \\
\hline $1-2,43-44$ & 1.9 & 63.9 & 2.51 & 0.20 & 12.4 & n.d. & n.d. & 370 & 189 \\
\hline $1-3,113-114$ & 4.1 & 55.3 & 3.50 & 0.20 & 17.3 & 0.48 & 0.27 & n.d. & n.d. \\
\hline $1-4,43-44$ & 4.9 & 51.6 & 1.49 & 0.43 & 3.5 & n.d. & n.d. & 241 & 159 \\
\hline $1-4,144-145$ & 5.9 & 50.2 & 1.80 & 0.40 & 4.5 & n.d. & n.d. & 231 & 163 \\
\hline $1-5,43-44$ & 6.4 & 43.1 & 1.31 & 0.36 & 3.6 & n.d. & n.d. & 327 & 204 \\
\hline $1-5,113-114$ & 7.1 & 43.1 & 2.86 & 0.28 & 10.1 & 0.50 & 0.33 & n.d. & n.d. \\
\hline $2-1,43-44$ & 8.2 & n.d. & 1.56 & 0.41 & 3.8 & n.d. & n.d. & 354 & 189 \\
\hline $2-1,113-114$ & 8.9 & 57.6 & 2.93 & 0.38 & 7.8 & 0.50 & 0.40 & n.d. & n.d. \\
\hline $2-2,43-44$ & 9.7 & n.d. & 2.73 & 0.53 & 5.1 & n.d. & n.d. & 364 & 154 \\
\hline $2-3,43-44$ & 11.2 & 44.0 & 3.56 & 0.60 & 6.0 & n.d. & n.d. & 345 & 116 \\
\hline $2-3,113-114$ & 10.4 & 43.3 & 5.05 & 0.32 & 16.0 & 0.45 & 0.38 & n.d. & n.d. \\
\hline $2-4,43-44$ & 12.7 & 55.8 & 2.25 & 0.45 & 5.0 & n.d. & n.d. & 321 & 151 \\
\hline $2-5,43-44$ & 14.3 & 51.2 & 1.68 & 0.34 & 5.0 & n.d. & n.d. & 476 & 140 \\
\hline $2-6,43-44$ & 15.8 & 52.7 & 2.27 & 0.41 & 5.6 & n.d. & n.d. & 285 & 141 \\
\hline $2-7,43-44$ & 17.3 & 51.2 & 4.77 & 0.36 & 13.2 & n.d. & n.d. & 242 & 85 \\
\hline $3-1,43-44$ & 17.9 & 62.7 & 3.59 & 0.27 & 13.3 & n.d. & n.d. & 299 & 181 \\
\hline $3-2,43-44$ & 19.4 & 62.1 & 3.38 & 0.28 & 11.9 & n.d. & n.d. & 309 & 133 \\
\hline $3-2,127-128$ & 20.3 & 51.0 & 4.58 & 0.37 & 12.4 & n.d. & n.d. & 343 & 133 \\
\hline $3-2,138-139$ & 20.4 & 30.7 & 6.83 & 0.66 & 10.3 & n.d. & n.d. & 487 & 109 \\
\hline $3-3,43-44$ & 20.9 & 54.6 & 3.20 & 0.30 & 10.5 & n.d. & n.d. & 415 & 157 \\
\hline $3-3,113-114$ & 21.6 & 69.2 & 3.95 & 0.21 & 18.6 & 0.33 & 0.36 & n.d. & n.d. \\
\hline $3-4,43-44$ & 22.4 & 60.2 & 2.18 & 0.27 & 8.2 & n.d. & n.d. & n.d. & n.d. \\
\hline $3-4,144-145$ & 23.4 & 56.4 & 0.71 & 0.49 & 1.5 & n.d. & n.d. & 220 & 269 \\
\hline $3-5,43-44$ & 23.9 & 54.8 & 1.23 & 0.41 & 3.0 & n.d. & n.d. & 259 & 162 \\
\hline $3-6,43-44$ & 25.4 & 50.8 & 1.66 & 0.63 & 2.6 & n.d. & n.d. & 185 & 104 \\
\hline $4-3,43-44$ & 30.5 & 50.3 & 1.01 & 0.47 & 2.2 & 0.37 & 0.52 & n.d. & n.d. \\
\hline $6-4,144-145$ & 52.3 & 63.9 & 2.04 & 0.51 & 4.0 & n.d. & n.d. & 399 & 164 \\
\hline $7-2,149-150$ & 58.0 & 60.5 & 4.50 & 0.40 & 11.3 & n.d. & n.d. & 113 & n.d. \\
\hline $7-2,43-44$ & 56.9 & 54.1 & 1.82 & 0.38 & 4.8 & 0.41 & 0.45 & 279 & 150 \\
\hline $8-1,43-44$ & 66.2 & 63.7 & 3.12 & 0.19 & 16.7 & 0.31 & 0.35 & 397 & 116 \\
\hline $8-4,140-150$ & 71.8 & 56.2 & 1.09 & 0.53 & 2.1 & n.d. & n.d. & 251 & 179 \\
\hline $9-2,43-44$ & 77.3 & 60.7 & 3.85 & 0.36 & 10.8 & 0.37 & 0.45 & 381 & 104 \\
\hline $9-4,144-145$ & 81.3 & 57.8 & 2.42 & 0.29 & 8.4 & n.d. & n.d. & 452 & 123 \\
\hline $10-6,80-82$ & 93.4 & 57.3 & 2.27 & 0.29 & 7.8 & 0.29 & 0.46 & n.d. & n.d. \\
\hline $11-1,149-150$ & 95.9 & 54.6 & 1.09 & 0.70 & 1.5 & n.d. & n.d. & 254 & 166 \\
\hline $13-4,119-120$ & 119.8 & 63.3 & 3.49 & 0.43 & 8.2 & n.d. & n.d. & 437 & 110 \\
\hline $14-2,149-150$ & 126.8 & 65.3 & 3.29 & 0.41 & 8.1 & n.d. & n.d. & 416 & 102 \\
\hline $14-3,70-71$ & 127.5 & 64.9 & 2.97 & 0.29 & 10.1 & 0.52 & 0.33 & 417 & 81 \\
\hline $15-6,0-1$ & 140.9 & 61.1 & 2.51 & 0.52 & 4.8 & n.d. & n.d. & 422 & 118 \\
\hline $17-2,0-1$ & 154.3 & 63.5 & 2.06 & 0.53 & 3.9 & n.d. & n.d. & 379 & 119 \\
\hline $19-4,64-65$ & 177.2 & 51.7 & 1.76 & 0.52 & 3.4 & n.d. & n.d. & 266 & 136 \\
\hline $20-4,30-31$ & 186.7 & 61.9 & 2.65 & 0.54 & 4.9 & n.d. & n.d. & 395 & 114 \\
\hline $21-6,45-46$ & 199.4 & 58.8 & 2.11 & 0.50 & 4.2 & 0.49 & 0.47 & 402 & 100 \\
\hline $22-3,29-30$ & 204.4 & 56.2 & 2.92 & 0.51 & 5.8 & 0.39 & 0.53 & 392 & 80 \\
\hline $23-2,0-1$ & 212.3 & 63.1 & 3.04 & 0.52 & 5.9 & n.d. & n.d. & 395 & 115 \\
\hline $24-3,0-1$ & 223.4 & 44.5 & 4.51 & 0.72 & 6.3 & n.d. & n.d. & n.d. & n.d. \\
\hline $25-5,43-44$ & 236.5 & 54.9 & 4.60 & 0.47 & 9.7 & 0.54 & 0.43 & 444 & 75 \\
\hline $26-4,24-25$ & 244.5 & 50.7 & 5.19 & 0.59 & 8.8 & 0.59 & 0.46 & n.d. & n.d. \\
\hline $27-2,43-44$ & 251.3 & 50.7 & 2.21 & 0.61 & 3.6 & 0.43 & 0.55 & n.d. & n.d. \\
\hline $28-2,48-49$ & 261.1 & 28.9 & 6.11 & 0.70 & 8.8 & 0.54 & 0.53 & n.d. & n.d. \\
\hline $29-6,119-120$ & 277.4 & 29.4 & 4.25 & 0.40 & 10.5 & n.d. & n.d. & 435 & 82 \\
\hline $30-1,0-1$ & 278.3 & 69.0 & 4.90 & 0.16 & 31.4 & n.d. & n.d. & 433 & 71 \\
\hline $31-2,144-145$ & 290.8 & 68.4 & 4.57 & 0.30 & 15.1 & 0.29 & 0.48 & n.d. & n.d. \\
\hline $32-5,119-120$ & 304.7 & 60.8 & 3.06 & 0.58 & 5.3 & n.d. & n.d. & 402 & 88 \\
\hline $32-6,43-44$ & 305.4 & 61.6 & 3.71 & 0.38 & 9.8 & 0.34 & 0.49 & n.d. & n.d. \\
\hline $33-2,78-79$ & 315.3 & n.d. & 4.62 & 0.71 & 6.5 & n.d. & n.d: & 397 & 76 \\
\hline $33-2,88-89$ & 315.4 & n.d. & 2.95 & 0.59 & 5.0 & n.d. & n.d. & 375 & n.d. \\
\hline $33-2,118-119$ & 315.7 & n.d. & 3.93 & 0.53 & 7.4 & n.d. & n.d. & 393 & 104 \\
\hline $33-2,138-139$ & 315.9 & n.d. & 3.25 & 0.73 & 4.5 & n.d. & n.d. & 375 & n.d. \\
\hline $33-2,148-149$ & 316.0 & n.d. & 3.59 & 0.69 & 5.2 & n.d. & n.d. & 369 & 110 \\
\hline $33-3,20-21$ & 316.2 & n.d. & 4.07 & 0.64 & 6.4 & n.d. & n.d. & 374 & 91 \\
\hline $33-3,28-29$ & 316.4 & n.d. & 3.17 & 0.74 & 4.3 & n.d. & n.d. & 353 & 115 \\
\hline $33-3,38-39$ & 316.4 & n.d. & 2.91 & 0.67 & 4.3 & n.d. & n.d. & 360 & 112 \\
\hline $33-3,48-49$ & 316.5 & n.d. & 3.32 & 0.68 & 4.9 & n.d. & n.d. & 388 & 99 \\
\hline $33-3,8-9$ & 316.1 & n.d. & 3.90 & 0.81 & 4.8 & n.d. & n.d. & 388 & 113 \\
\hline $33-4,40-41$ & 312.0 & 54.6 & 4.66 & 0.49 & 9.4 & 0.45 & 0.49 & n.d. & n.d. \\
\hline $36-6,0-1$ & 333.6 & 35.7 & 2.91 & 1.11 & 2.6 & n.d. & n.d. & 399 & 111 \\
\hline \multicolumn{2}{|c|}{ Mean } & 54.9 & & 0.47 & 6.8 & 0.42 & 0.43 & 355 & 129 \\
\hline \multicolumn{2}{|c|}{ Standard deviation } & 9.2 & 1.31 & 0.18 & n.d. & 0.09 & 0.08 & 77 & 39 \\
\hline \multicolumn{2}{|c|}{ Minimum } & 28.9 & 0.71 & 0.16 & 1.5 & 0.27 & 0.27 & 113 & 71 \\
\hline \multicolumn{2}{|l|}{ Maximum } & 69.2 & 6.83 & 1.11 & 31.4 & 0.59 & 0.55 & 487 & 269 \\
\hline
\end{tabular}

n.d. $=$ not determined. 

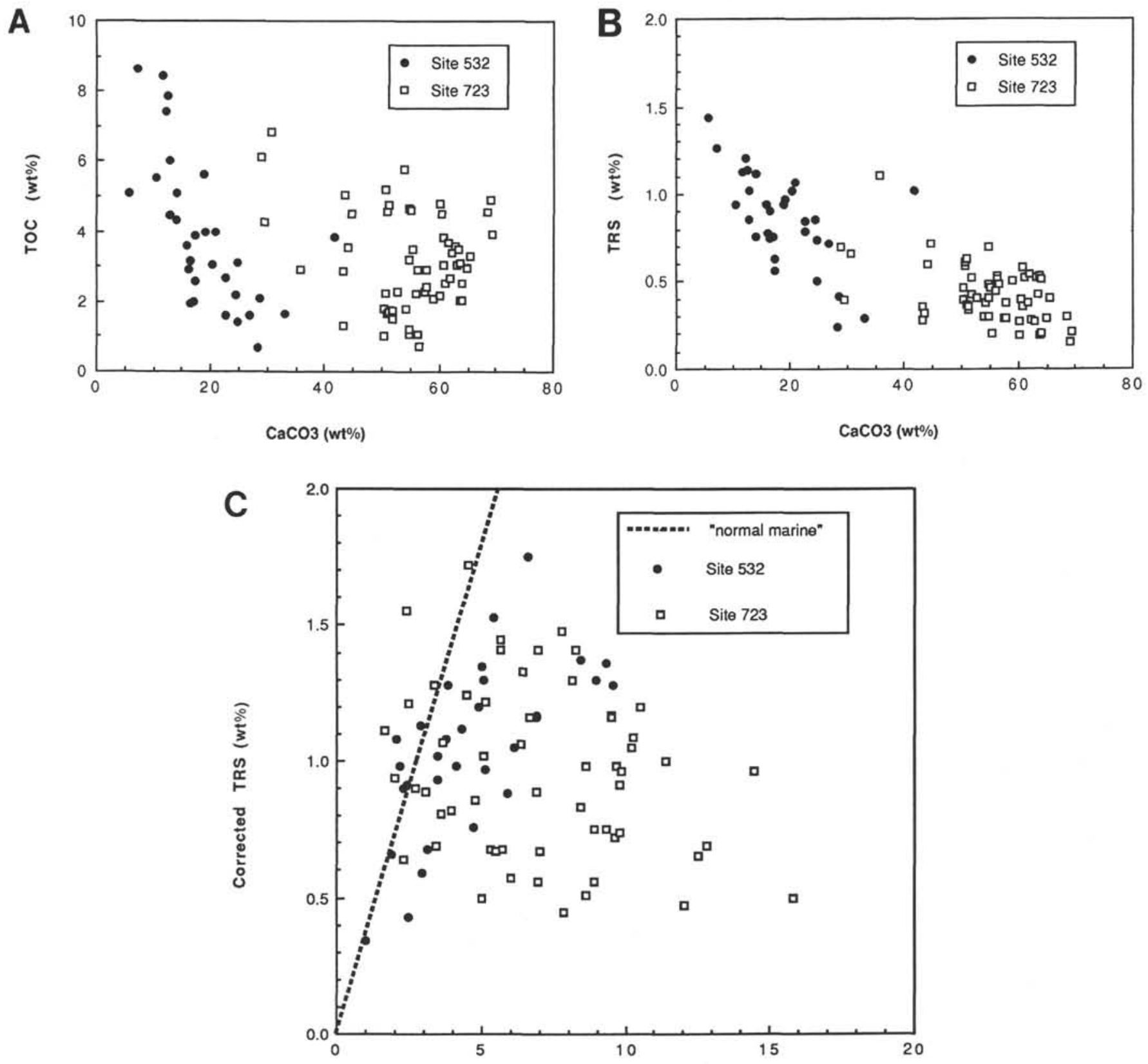

Corrected TOC (wt\%)

Figure 6. A. Relationships between $\mathrm{CaCO}_{3}$ and $\mathrm{TOC}$ for samples studied from Sites 723 and 532. B. Relationships between $\mathrm{CaCO}_{3}$ and $\mathrm{TRS}$ for samples studied from Sites 723 and 532. C. Carbonate-corrected TOC and TRS plot for Sites 532 and 723 shows considerable overlap of the two sites. $\mathrm{C} / \mathrm{S}$ ratios do not conform to the "normal marine" ratio of 2.8 .

minerals, $\mathrm{H}_{2} \mathrm{~S}$ mobility, and maturation of organic matter, can significantly influence C/S ratios. Raiswell and Berner (1987) emphasized the utility of using vitrinite reflectance to estimate post-depositional loss of organic carbon from sediments, which in turn results in altered $\mathrm{C} / \mathrm{S}$ ratios. Their results, along with those of this study, point to both the need for and potential utility of a more sophisticated approach for characterization of sedimentary organic carbon, when it is to be used with reduced sulfur concentrations.
The hydrogen index and organic carbon concentration are high enough in the organic-rich sediments at Site 532 to support sulfate reduction. These observations, in conjunction with the fact that sulfate was present in interstitial waters (Gieskes et al., 1984; Prell, Niitsuma, et al., 1989) and that DOP is rarely higher than 0.5 , suggest that only a fraction of organic matter, whether it be labile or not, is utilized during bacterial sulfate reduction in the diagenetic environment of marine upwelling sediments. Pyrite production in these sediments does not proceed to 
Table 3. Results of analyses for Site $\mathbf{7 2 2}$.

\begin{tabular}{lrcccccc}
\hline $\begin{array}{l}\text { Core, section, } \\
\text { interval }(\mathrm{cm})\end{array}$ & $\begin{array}{r}\text { Depth } \\
\text { (mbsf) }\end{array}$ & $\begin{array}{c}\mathrm{CaCO}_{3} \\
\text { (wt\%) }\end{array}$ & $\begin{array}{c}\text { TOC } \\
\text { (wt\%) }\end{array}$ & $\begin{array}{c}\text { TRS } \\
\text { (wt\%) }\end{array}$ & \multicolumn{1}{c}{ C/S } & HI & OI \\
\hline $1-4,144-145$ & 5.94 & 63.1 & 0.35 & 0.07 & 5.0 & 223 & n.d. \\
$3-4,114-115$ & 25.04 & 58.1 & 0.83 & 0.37 & 2.2 & 234 & 586 \\
$6-4,114-115$ & 53.84 & 69.9 & 1.13 & 0.33 & 3.4 & 182 & 441 \\
$9-4,119-120$ & 82.48 & 56.3 & 2.10 & 0.24 & 8.8 & 277 & 303 \\
$12-4,119-120$ & 111.59 & 78.3 & 0.41 & 0.20 & 2.1 & 154 & 865 \\
$15-5,145-150$ & 142.35 & 87.1 & 0.21 & 0.08 & 2.5 & 105 & n.d. \\
$16-2,29-30$ & 146.39 & 81.6 & 0.58 & 0.08 & 7.0 & 188 & 579 \\
$16-2,20-21$ & 146.30 & 86.8 & 0.02 & 0.09 & 0.2 & n.d. & n.d. \\
$16-2,25-26$ & 146.35 & 84.1 & 0.44 & 0.13 & 3.5 & 157 & 661 \\
$16-2,34-35$ & 146.44 & 79.0 & 1.03 & 0.25 & 4.2 & 226 & 376 \\
$16-2,38-40$ & 146.49 & 71.2 & 1.68 & 0.42 & 4.0 & 302 & 325 \\
$16-2,43-44$ & 146.53 & 71.1 & 1.94 & 0.22 & 8.7 & 258 & 280 \\
$16-2,48-49$ & 146.58 & 67.1 & 1.83 & 0.40 & 4.6 & 289 & 289 \\
$16-2,56-57$ & 146.66 & 61.2 & 1.98 & 0.43 & 4.6 & 267 & 301 \\
$16-2,60-61$ & 146.70 & 57.1 & 1.90 & 0.55 & 3.5 & 281 & 300 \\
$16-2,65-67$ & 146.75 & 56.1 & 1.88 & 0.55 & 3.4 & 249 & 289 \\
$16-2,69-70$ & 146.79 & 56.6 & 2.06 & 0.53 & 3.9 & 292 & 292 \\
& & & & & & & \\
Mean & & 69.7 & 1.20 & 0.29 & 4.1 & 230 & 421 \\
Standard deviation & 11.3 & 0.76 & 0.17 & n.d. & 58 & 182 \\
Minimum & & 56.1 & 0.02 & 0.07 & 0.2 & 105 & 280 \\
Maximum & & 87.1 & 2.10 & 0.55 & 8.8 & 302 & 865 \\
\hline
\end{tabular}

n.d. $=$ not determined.

depletion of one of the components of the system, and sulfate reduction and $\mathrm{H}_{2} \mathrm{~S}$ production appear to be limited by an as yet unknown process. The nearly identical TRS concentrations (on a carbonate-free basis) at Sites 532 and 723 may be indicative of such a limiting factor.

\section{CONCLUSIONS}

An examination of the organic carbon-authigenic sulfide system in Neogene and Quaternary sediments from the Benguela and Oman upwelling systems indicates that $\mathrm{C} / \mathrm{S}$ relationships in organic-rich sediments do not conform with those encountered in "normal marine" sediments. The primary difficulty appears to be in our understanding of what limits bacterial decomposition of the organic matter via sulfate reduction in this type of sedimentary environment.

Our results also further demonstrate that care must be used in applying carbon-sulfur relations to interpretation of paleoenvironments. In upwelling sediments with high organic carbon contents ( $>3 \mathrm{wt} \%$ ), the $\mathrm{C} / \mathrm{S}$ ratios are not, at present, applicable as paleoenvironmental indicators. Primary complicating factors appear to be early diagenetic competition of organic species and possibly of metals for reduced sulfur ions, as well as subtle differences in the "palatability" of organic matter. Prevalence of oxic or anoxic conditions at the sediment/water interface during deposition appears to have no effect on the abundance of reduced sulfur.

\section{ACKNOWLEDGMENTS}

K.-C. E. gratefully acknowledges financial support by USSAC and technical support by ODP during the course of this study.

\section{REFERENCES}

Berner, R. A., 1970. Sedimentary pyrite formation. Am. J. Sci., 268:123.

1982. Burial of organic carbon and pyrite sulfur in the modern ocean: its geochemical and environmental significance. $\mathrm{Am}$. $J$. Sci., 282:451-473.

1984. Sedimentary pyrite formation: an update. Geochim. Cosmochim. Acta, 48:605-615.

1985. Sulfate reduction, organic matter decomposition, and pyrite formation. Phil. Trans. R. Soc. London, 48:25-38.
Berner, R. A., and Raiswell, R., 1983. Burial of organic carbon and pyrite sulfur ion sediments over Phanerozoic time: a new theory. Geochim. Cosmochim. Acta, 47:855-862.

1984. C/S method for distinguishing freshwater from marine sedimentary rocks. Geology, 12:365-368.

[Author: please add reference for Canfield (1989) cited just before "Results" section.]

Canfield, D. E., Raiswell, R., Westrich, J. T., Reeves, C. M., and Berner, R. A., 1986. The use of chromium reduction in the analysis of reduced inorganic sulfur in sediments and shale. Chem. Geol., 54:149-155.

Davis, H. R., Byers, C. W., and Dean, W. E., 1988. Pyrite formation in the lower Cretaceous Mowry Shale: Effect of organic matter type and reactive iron content. Am. J. Sci., 288:873-890.

Davison, W., Lishman, J. P., and Hilton, J., 1985. Formation of pyrite in freshwater sediments: implications for $\mathrm{C} / \mathrm{S}$ ratios. Geochim. Cosmochim. Acta., 49:1615-1620.

Dean, W. E., Arthur, M. A., and Claypool, G. E., 1986. Depletion of ${ }^{13} \mathrm{C}$ in Cretaceous marine organic matter: Source, diagenesis, or environmental signal? Mar. Geol., 70:119-157.

Emeis, K.-C., and Morse, J. W., 1990. Organic carbon, reduced sulfur, and iron relationships in sediments of the Peru margin, ODP Sites 680 and 688. In Suess, E., von Huene, R., et al., Proc. ODP, Sci. Results, 112. College Station, TX (Ocean Drilling Program).

Emeis, K.-C., Whelan, J. K., and Tarafa, M., in press. Sedimentary and geochemical expressions of oxic and anoxic conditions on the Peru shelf. In Tyson, R., and Pearson, T. (Eds.) Continental Shelf Anoxia. Geol. Soc. London Spec. Publ.

Espitalié, J., Deroo, G., and Marquis, F., 1985. La pyrolyse Rock-Eval et ses applications. Rev. Inst. Fr. Pet., 40:563-579.

Gieskes J. M., Johnston, K., Boehm, W., and Nohara, M., 1984. Interstitial water studies, DSDP Leg 75. In Hay, W. W., Sibuet, J.-C., et al., Init. Repts., DSDP, 75. Washington (U. S. Govt. Printing Office), 959-963.

Goldhaber, M. B., and Kaplan, I. R., 1974. The sulfur cycle. In Goldberg, E. D. (Ed.) The Sea, Vol. 5, New York (John Wiley), 569-655.

Hay, W. W., Sibuet, J.-C., et al., 1984. Init. Repts. DSDP 75, Washington (U. S. Govt. Printing Office).

Hunt, J. M., 1972. Distribution of carbon in crust of Earth. AAPG Bull., 56: 2273-2277.

Katz, B. J., 1983. Limitations of 'Rock-Eval' pyrolysis for typing organic matter. Organic Geochem., 4:195-199.

Leventhal, J. S., 1983. An interpretation of carbon and sulfur relationships in Black Sea sediments as indicators of environments of deposition. Geochim. Cosmochim. Acta., 47:133-137.

1987. Carbon and sulfur relationships in Devonian shales from the Appalachian Basin as an indicator of environment of deposition. Am. J. Sci., 287;33-49.

Meyers, P. A., Brassell, S. C., Huc, A. Y., Barron, E. J., Boyce, R. E., Dean, W. E., Hay, W. W., Keating, B. H., McNulty, C. L., Noharra, M., Schallreuter, R. E., Sibuet, J., Steinmetz, J. C., Stow, D., and Stradner, H., 1983. Organic geochemistry of sediments recovered by DSDP/IPOD Leg 75 under the Benguela Current. In Thiede, J., and Suess, E., (Eds.), Coastal Upwelling: Its Sediment Record, Part B, New York (Plenum Press), 453-466.

Meyers, P. A., Brassell, S.C., and Huc, A.Y., 1984. Geochemistry of organic carbon in South Atlantic Sediments from DSDP Leg 75. In Hay, W.W., Sibuet, J.-C., et al., Init. Repts. DSDP 75/2, Washington (Govt. Printing Office), 967-981.

Meyers, P. A., and Dunham, K. W., 1984. Geolipid comparison of biogenic sediments from Deep Sea Drilling Project Holes 530B, Angola Basin, and 532, Walvis Ridge. In Hay, W. W., Sibuet, J.-C., et al., Init. Repts. DSDP 75/2, Washington (Govt. Printing Office), 10891095.

Pratt, L. M., Claypool, G. E., and King, J. D., 1986. Geochemical imprint of depositional conditions on organic matter in laminated-bioturbated interbeds from fine-grained marine sequences. Mar. Geol., 70:67-84.

Prell, W. D., Niitsuma, N., et al., 1989. Proc. ODP, Init. Repts., 117: College Station, TX (Ocean Drilling Program).

Raiswell, R., and Berner, R. A., 1985. Pyrite formation in euxinic and semi-euxinic sediments. Am. J. Sci., 285:710-724.

1987. Organic carbon losses during burial and thermal maturation of normal marine shales. Geology., 15:853-856. 
Rullkötter, J., Mukhopadhyay, P. K., and Welte, D. H., 1984. Geochemistry and petrography of organic matter in sediments from Hole 530A, Angola Basin, and Hole 532, Walvis Ridge, Deep Sea Drilling Project. In Hay, W. W., Sibuet, J.-C., et al., Init. Repts. DSDP 75/2, Washington (U.S. Govt. Printing Office), 1069-1087.

Sweeney, R. E., 1972. Pyritization during diagenesis in marine sediments, [Ph. D. dissert.]. Univ. California, Los Angeles.

Westrich, J. T., 1983. The consequences and controls of bacterial sulfate reduction in marine sediments [Ph.D. dissert.]. Yale Univ., New Haven.

Westrich, J. T., and Berner, R. A., 1984. The role of sedimentary organic matter in bacterial sulfate reduction: The $\mathrm{G}$ model tested. Limnol. Oceanogr., 29:236-249.
Zhabina, N. N., and Volkov, I. I., 1978. A method of determination of various sulfur compounds in sea sediments and rocks. In Krumbein, W. E., (Ed.), Environmental Biogeochemistry and Geomicrobiology, Vol. 3: Methods, Metals and Assessment: Ann Arbor (Ann Arbor Sci. Publ.): 735-746.

Date of initial receipt: 28 June 1989

Date of acceptance: 19 February 1990

Ms 117B-155 